\title{
$\mathrm{D}$ 相乳化法による微細 $\mathrm{O} / \mathrm{W}$ エマルションの 調製法開発と工業化
}

\author{
鷺谷 広道・鍋田 一男・永井 昌義 \\ ポーラ横浜研究所 (广 221 横浜市神奈川区高島台 27-1)
}

\section{A New Preparing Method for Fine O/W Emulsions by D Phase Emulsification and Their Application to Cosmetic Industry}

\author{
Hiromichi SAGITANI, Kazuo NABETA, and Masayoshi NAGAI \\ POLA Yokohama Research Laboratories \\ (27-1, Takashimadai, Kanagawa-ku, Yokohama-shi, $\bar{\top} 221)$
}

A new emulsification technique for producing fine $\mathrm{O} / \mathrm{W}$ emulsions, $\mathrm{D}$ phase emulsification, has been developed and elucidated the emulsification mechanism by using phase diagrams. The process of $D$ phase emulsification begins with the formation of isotropic surfacatant solution, followed by formation of an oil-in-surfactant (O/D) gel emulsion by dispersion of oil in the surfactant solution, and finally formation of an $\mathrm{O} / \mathrm{W}$ emulsion by the addition of an aqueous phase to the gel emlsion. The characteristics of $\mathrm{D}$ phase emulsification are as follows : (1) it is easy to produce submicron $\mathrm{O} / \mathrm{W}$ emulsion in many types of oils and surfactants, (2) strict HLB adjustment is not necessary, (3) it is possible to reduce the emulsifier content. This emulsification method has been applied to develop new types of cosmetics.

\section{1 はじめに}

エマルションと化粧品よの係わりは深く, 製品の3 4 割はエマルションを利用した剤型であると思われる。 それ故かエマルションの作製法についての化粧品関連企 業による研究は比較的多く行われている。今回日本油化 学協会賞工業技術賞の対象亡なった D相乳化法もその 1 つということになる。我々は製品開発の一環として安定 エマルションを作製する方法の開発を行ってきた。同時 に一研究者としてよ゙のような乳化メカニズムで微細かつ 安定なエマルションが形成されるのかに興味をもち検討 してきた。本稿では $\mathrm{D}$ 相乳化法の開発の経緯と研究内容 を要約して紹介させていただく。エマルションの作製方 法を大きく分けると界面化学的手法と機械的手法に分類 できる。界面化学的手法を用いて微細で女定なエマル ション粒子を作るには乳化剂の親水性・親油性バランス (HLB) の調整, 乳化温度, 各成分の添加方法等に工夫 がなくては不可能である。機械力を利用する場合でも高 せん(剪)断力型や高圧型の乳化機が必要となってくる。 界面活性剂の力を上手に引き出すことによって乳化物を

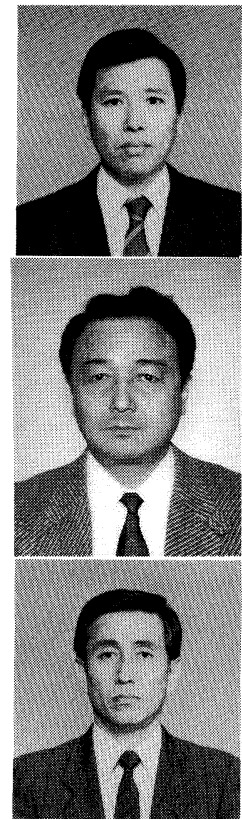

作製する方法として転相温度乳化法 ${ }^{1) ~ 2)}$, 転相乳化法 (反 転乳化法 $)^{3)}$, ゲル乳化法 ${ }^{4)}$, 非水乳化法 ${ }^{5)}$, 液晶乳化 法 $^{6)}$ が開発されてきた。このように複数の方法や装置が 利用されている事実は 1 つの乳化方法ですべてのエマル ション剤型をカバーすることができないことを物語って いる。機械力を使って乳化をする場合，エマルション粒 子のサブミクロン化には高圧乳化機 ${ }^{7)}$ の利用が必要であ る。高圧乳化機は少品種大量生産には適しているが, 多 品種小量生産が必要な業種には使いにくい。またクリ一 厶殽型や高粘度乳化系への適用には向かない。界面化学 的手法は夕イプの異なるエマルション剂型への適用が容 易であり，高価な装置を必要とせず，エネルギー消費量 が少ないという点では優れている。しかし手間の点では 機械による方法にかなわない。故に個々の方法における 技術的発展が今後共必要であると思われる。我々はこれ まで乳化が難しいとされていた油や乳化剂系において, 微細 $\mathrm{O} / \mathrm{W}$ エマルションの新しい界面化学的作製法を開 発し，その乳化メカニズムを明らかにした。すなわちD 相乳化法である。その概要を 2 章以下で述べていきたい。 


\section{$2 \mathrm{D}$ 相乳化法の手順}

乳化物の基本構成成分は界面活性剂・油・水である が, D 相乳化では第 4 の成分として多価アルコールを用 い, 微細 $\mathrm{O} / \mathrm{W}$ エマルションを形成させる。D相乳化法 のプロセスは水と多価アルコールを含んだ界面活性剂等 方性溶液から出発し, 油相をこの界面活性剂溶液に分散 させることによって O/D ゲルエマルションを形成させ る。このゲルエマルションに水相を添加することにより $\mathrm{O} / \mathrm{W}$ エマルションとする方法である。 D相乳化法のプ ロセスを Fig. -1 に示す ${ }^{8)}$ 。本法は 2 つのステップによ り成り立っているが, 各ステップの始点と終点における 状態写真を Fig. - 1 中に示す (図中の A, B, C 点)。A は無色透明の溶液であるが,ここに油が添加されてBに 至ると無色透明のゲルとなる。 $\mathrm{B}$ に水が添加されて $\mathrm{C} に$ なるとエマルション状態になる。この透明ゲル状態を通 過する事が微細エマルション形成に必要である。ここで 第 4 の成分として多価アルコールを利用するようになっ た経緯を簡単に述べておきたいと思う。本研究を始める 以前に著者は化粧品用エマルションの作製に広く利用さ れている転相乳化法のメカニズム解明の研究を行った。 そこにおいて微細エマルション粒子の作製には連続相が 界面活性剤である $\mathrm{O} / \mathrm{D}$ エマルションを作ることが重要 であることを示した。しかしながら, 界面活性剤連続相 は液晶を形成する事が多く, 例えばラメラ液晶が形成さ 机るとエマルションは容易に合一してしまい, ヘキサゴ ナル液晶の場合は系が非常に硬く, 油滴をそこに分散さ せることは困難であった。多価アルコールは界面活性剂 の液晶形成を阻害する効果があり, 転相乳化法の一部の 系で $\mathrm{O} / \mathrm{D}$ エマルションの形成が容易であったことと,
界面活性剂を含んだ糖水溶液や多価アルコール中に油を 分散させ, 安定エマルションとする方法に関する特許が すでにあったこと ${ }^{5) .9)}$ から，多価アルコールを乳化の過 程で高濃度で利用した場合のエマルション形成に対する 影響を検討してみることにした。

\section{D相乳化法のメカニズム}

ゲルエマルション形成までの乳化プロセスを相図上に 示したものが Fig.-2である ${ }^{10)}$ 。D相乳化は点 A ら 出発し, 油頂点に向かって進む。等方性界面活性剤溶液 領域を越えて油が添加されると系は白濁してくる。この 相図上には界面活性剂相と油相を分ける臨界点 $\mathrm{P}_{2}$ のみ

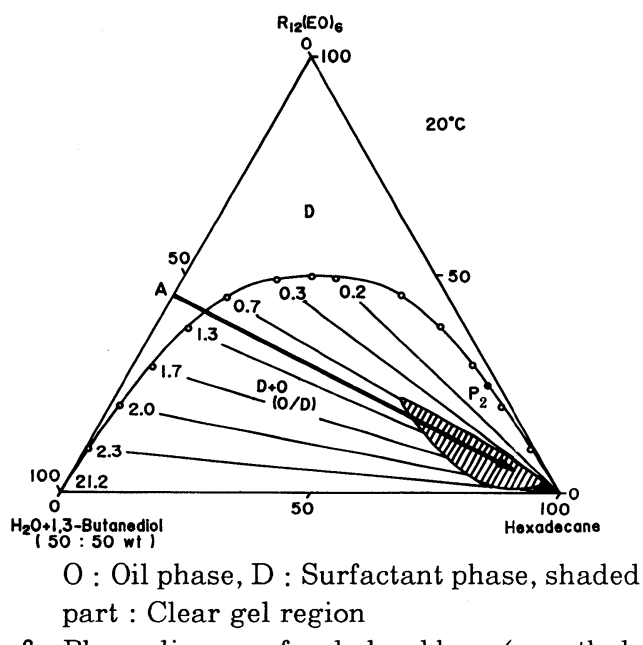

Fig. -2 Phase diagram for dodecyl hexa(oxyethylene) ether/hexadecane $/ 50 \mathrm{wt} \%$ 1,3-butanediol aqueous solution system ${ }^{10)}$.

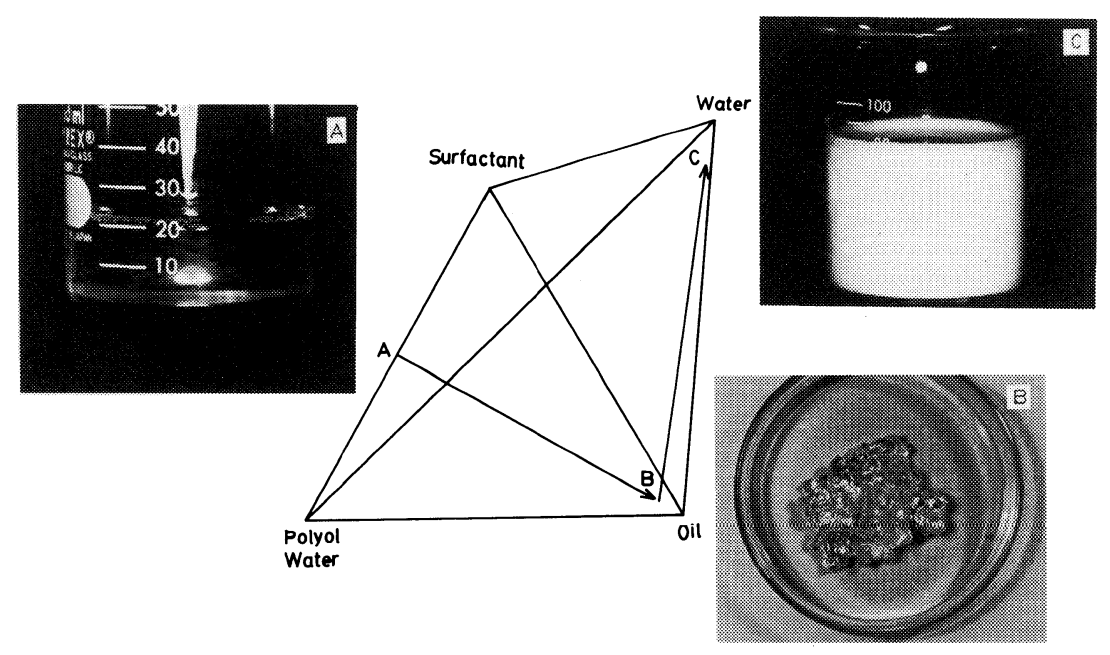

A : Isotropic surfactant solution, B : Cleargel, $\mathrm{C}: \mathrm{O} / \mathrm{W}$ emulsin

Fig. -1 Schematic procedure of $D$ phase emulsification. 
が存在するので, この白濁領域は界面活性剂 相+油相 (D+O) から成っている。油の組成比が $70 \mathrm{wt} \%$ を越え るようになると, 系は透明ゲル状態になる (Fig. - 2 の 斜線部分)。ゲルは相図中の 2 相領域に存在するため, エマルションであることは明白である。分散質と分散媒 の組成を明らかにするため, 遠心分離により 2 層分離し, 各層の成分をガスクロマトグラフィーによって分析し た。分析結果に基づくタイラインをFig.-2に示す。こ の透明ゲルはほとんど油よりなる内相と等方性界面活性 剤溶液よりなる連続相から成り立っている。ゲルの電子 顕微鏡写真を Fig. -3 に示す ${ }^{8)}$ 。内相比が $90 \mathrm{wt} \%$ にも なっているゲルの油滴はへキサゴナル型に詰まっている のが観察される。連続相は薄いネットワーク構造を取っ

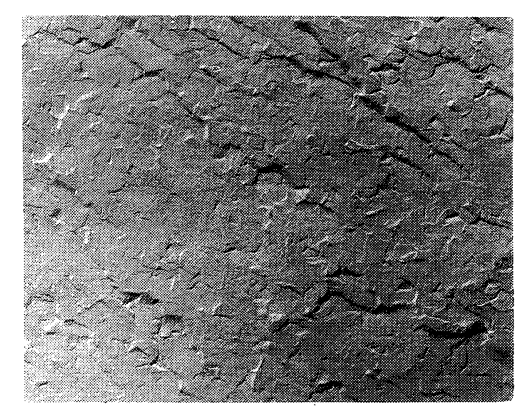

Fig. -3 Electron microphotograph of the clear $\mathrm{gel}^{8)}$
ている。界面活性剤連続相の屈折率は水相より油の值に 近く, 内相と連続相の屈折率の差は小さい ${ }^{9)}$ 。この薄い 膜の連続相と屈折率の差が少ないことからゲルエマル ションは透明になっているのであろう。油と D相間の界 面張力值はゲルエマルション形成の可否に影響する。安 定なゲルエマルションは界面張力が $0.5 \sim 2.0 \mathrm{dyn} / \mathrm{cm}$ の範囲で形成される (Fig. - 2)。エマルションの合一は 界面張力が低いほど起きやすいため, $0.5 \mathrm{dyn} / \mathrm{cm}$ 以下 では安定なエマルションとはならない。逆に界面張力値 の高い領域ではエマルション粒子が細かくならず安定な エマルションは得られない。

\section{D相乳化法における多価アルコールの役割}

透明ゲルエマルション形成に対する多価アルコールの 役割を理解するために, 界面活性剤/油/多価アルコール 水溶液よりなる相図を求めた $($ Fig. -4$)$ 。水が存在しな いオレイルニポリ (オキシエチレン) (6)=エーテル/流動 パラフィン/1,3-ブタンジオール系の相図は単純で, 1 相領域と 2 相領域が一つずつ現れる[Fig. -4 (a)]。1 相は等方性界面活性剂相 (D) であり, 2 相は界面活性 剂相+油相 $(\mathrm{D}+\mathrm{O})$ である $\left(\mathrm{P}_{2}\right.$ のみが存在するため)。 ゲルエマルションはこの系では形成されない。1,3-ブ タンジオールの一部を水に置き換えると, 界面活性剂相 中への油の溶解性は向上し, 油相と界面活性剂相を分け る臨界点 $\mathrm{P}_{2}$ は油頂点の方向に移動する。[Fig. -4

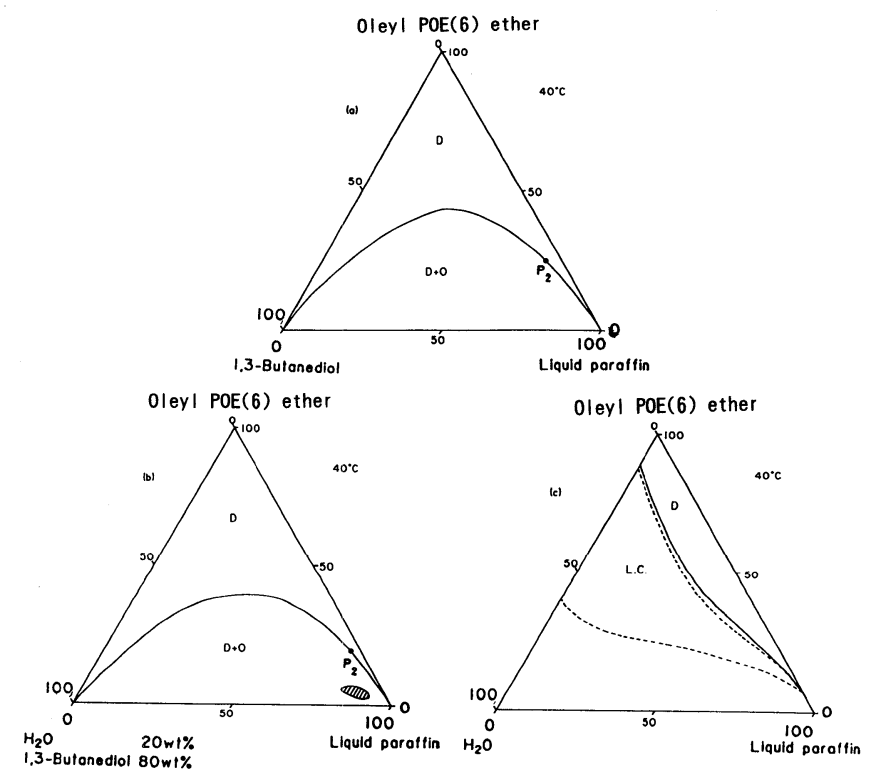

L.C. : lamellar liquid crystaline phase

Fig. -4 Phase diagram for oleyl poly (oxyetyhlene) (6) ether/liquid paraffin/1,3-butanediol aqueous solution system ${ }^{11}$. 
(b)］。この系ではゲルエマルションを形成する領域が 現れる。油の溶解度の増加と $\mathrm{P}_{2}$ 点の油頂点方向への移 動は界面活性剂の会合性が水添加で向上したことを示し ている。水添加で界面活性剂の会合性が向上することは アルカンジオール水溶液中における臨界ミセル形成濃度 $(\mathrm{cmc})$ が水の比率の向上によって, 低下することから も理解できる ${ }^{11)}$ 。オレイルニポリ(オキシエチレン) (6)= エーテル/流動パラフィン/水系になると, 等方性界面活 性剂相の代わりに, ラメラ液晶相領域が大きく広がる。 この系では再びゲルエマルションが形成されなくなる [Fig. -4 (c) ]。この系の 2 相領域において, 油はラメ ラ相と共存している。ラメラ相は系の HLB がちょうど 釣りあっているときに形成されるので ${ }^{22)}$, 油相之の間 には低い界面張力が存在しているはずである。極度に低 い界面張力は容易に合一が起こり ${ }^{13)}$, ゲルエマルショ ンを維持するには不向きである。アルカンジオールの乳 化系への添加は界面活性剂の親水性を向上させる ${ }^{14)}$ 。 ラメラ相を形成するような HLB一值をもつ界面活性剤 に対しては安定で細かいゲルエマルション形成に適した 界面張力を与える。一方, 界面活性剤の親水性を低下さ せるような多価アルコールであるグリセリン，ジグリセ リン，ポリエチレングリコールをD相乳化に用いる場合 は親水性の界面活性剂がゲルエマルション形成に適して いる。親水性界面活性剂は水の共存下に, へキサゴナル 液晶を形成する。へキサゴナル相は多量の油を分散する にはあまりにも硬い。多価アルコールはこの構造を破壊 し, 等方性界面活性剂溶液を与える。オレイル=ポリ(オ

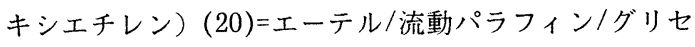
リン水溶液の相図を示す (Fig. -5)。ヘキサゴナル液晶 の代わりに等方性界面活性剂溶液が水相之界面活性剂頂 点を結ぶ線上に現れる。そして $\mathrm{O} / \mathrm{D}$ ゲルエマルション が 2 相領域に形成される。

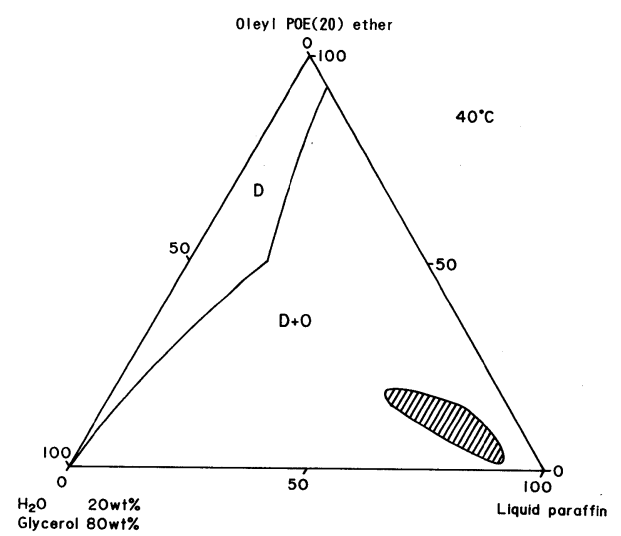

Fig. -5 Phase diagram for oleyl poly (oxyethylene) (20) ether/liquid paraffin/glycerol aqueous solution system ${ }^{13)}$.

\section{D相乳化法の特徵}

\section{$5 \cdot 1$ 植物油の乳化}

トリアシルグリセリンである植物油の乳化は炭化水素 やモノエステル油に比べて難しい。メカニカルスター ラーを使って植物油を乳化すると、エマルションの粒子 サイズは 2 $4 \mu \mathrm{m}$ 程度にしかならない ${ }^{15)}$ 。転相乳化を 用いて植物油をサブミクロンエマルションに乳化するの も困難である。この理由は相図を用いて理解することが できる。ドデシルニトリ (オキシエチレン)=エーテル/へ キサデカン $/ 1,3$-ブタンジオール $50 \mathrm{wt} \%$ 水溶液系は親 水性・親油性のバランスが整って, 水・油・界面活性剂 よりなる 3 相領域を与える $[\text { Fig. }-6(b)]^{16)}$ 。臨界点は 水之界面活性剂を分ける $\mathrm{P}_{1}$, そして油之界面活性剂を 分ける $\mathrm{P}_{2}$ が存在する。臨界点は水之油の界面活性剂相 中への溶解度を表す指針になる。へキサデカンをオリブ 油に置き換えると臨界点 $\mathrm{P}_{1}$ は消失し, 臨界点 $\mathrm{P}_{2}$ は油 頂点の方へ移動する [Fig.-6 (a) ]。すなわち, 界面活 性剂相中への油の溶解度は減少し, 逆に水相の溶解度は 増加する。また, 界面活性剂 1 液相を形成する最低界面 活性剂量はへキサデカン系で $28 \mathrm{wt} \%$ 必要であるのに 対して,オリブ油になると $57 \mathrm{wt} \%$ 必要になる。転相 乳化では乳化しようとする油を一度界面活性剤連続相 （ラメラ相）に溶解させることが, 微細粒子を得るのに 必要である ${ }^{3)}$ 。転相乳化に適するようにオリブ油の系で の HLB を整えるには親水性界面活性剂がより多く必要 となる。そうすると油の界面活性剤相への溶解度はさら に低下し, 微細エマルション粒子を得るためにはより多 量の乳化剂が必要となってくる。D相乳化ではラメラ液 晶を利用しないため, 親水性界面活性剂単独で乳化が可 能である。代表的な植物油として大豆油, 綿実油, サフ ラワー油,ひまし油をD相乳化を用いて乳化した。Fig.7 に示すように $2 \mathrm{wt} \%$ の乳化剤で $0.8 \mu \mathrm{m}$ のサブミク ロン粒子を得るこよができる。

\section{$5 \cdot 2$ 乳化安定性}

HLB 值の概念が 1949 年に Griffin によって提唱さ れて以来 ${ }^{17)}$, 微細エマルションの形成には乳化剂の HLB の調整が不可欠とされてきた。転相乳化法とD相 乳化法を用いて同じ系を乳化した場合の粒子径分布を示 す ${ }^{10)}$ 。転相乳化法によって作られたエマルションの粒 子径は乳化剂の HLBによって大きく変わる (Fig.-8)。 一方, D相乳化法によった場合には粒子径に大きな変化 は見られない (Fig. -9)。転相乳化ではその乳化過程で 多量の油を界面活性剂連続相中に溶解しなくてはなら ず, 可溶化量が HLBによって大きく変わることは周知 のことであり，これが転相乳化において，HLB の影響 が大きくでてくる理由である。D相乳化では油を界面活 性剂相に分散していくだけのため HLB の調整はそれほ 


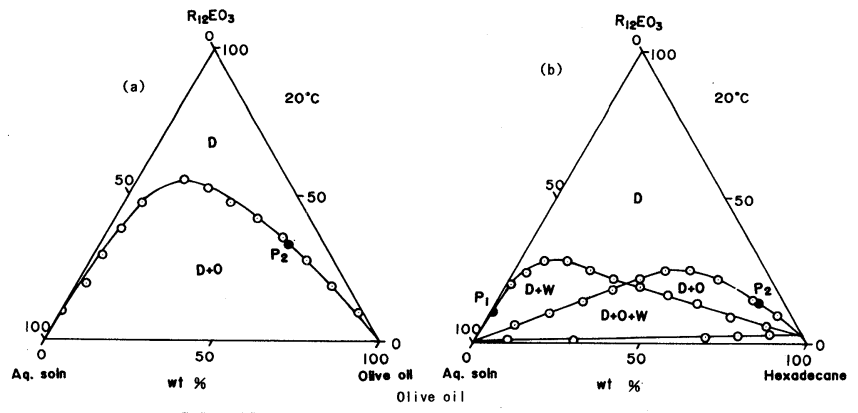

W : Water phase, $\mathrm{P}_{1}$ : Critical point dividing water phase and surfactant phase, $\mathrm{P}_{2}$ : Critical point dividing oil phase and surfactant phase

Fig. -6 Phase diagrams for the $\mathrm{R}_{12} \mathrm{EO}_{3}$ /olive oil (a) or hexadecane (b)/50 wt\% 1,3-butanediol aqueous solution system ${ }^{16)}$.
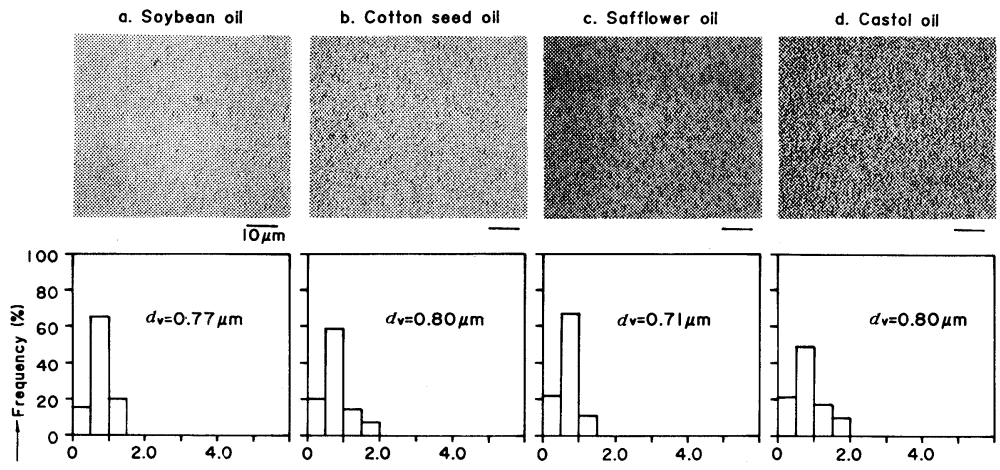

Fig.-7 Microphotographs and droplet size distribution of $\mathrm{O} / \mathrm{W}$ emulsions containing vegitable oils prepared by $\mathrm{D}$ phase emulsification ${ }^{16)}$.
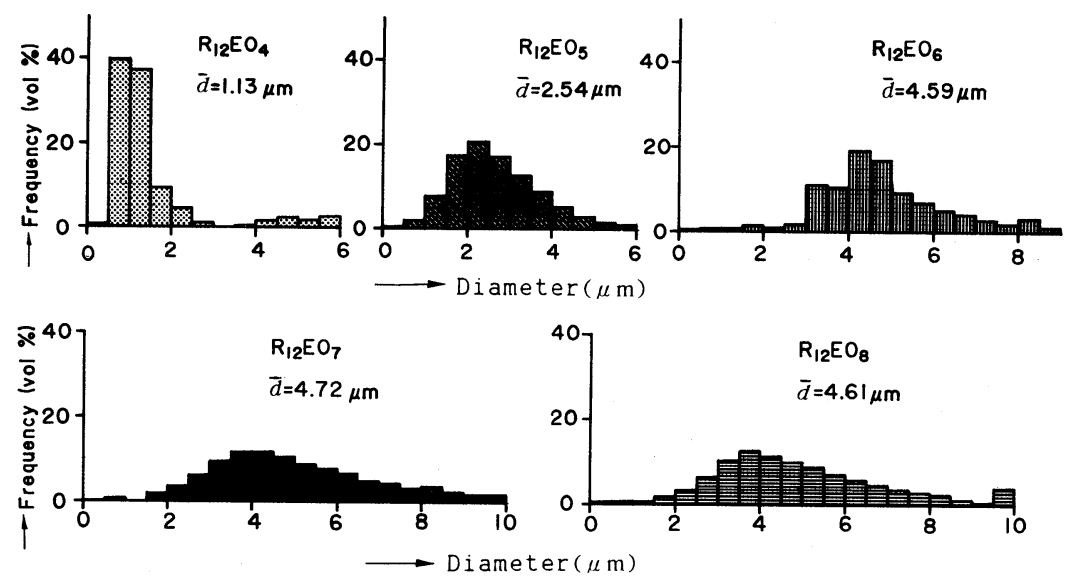

Fig.-8 Droplet size distribution of $\mathrm{O} / \mathrm{W}$ emulsions prepared by phase inversion emulsification ${ }^{12)}$.

ど重要ではなくなる。非イオン界面活性剤を乳化剤とし て用いたエマルションの物性(安定性, レオロジー特性)
は一般的に温度の影響を受けやすいが, 親水性界面活性 剤だけでエマルション調整ができるD相乳化法を用いれ 

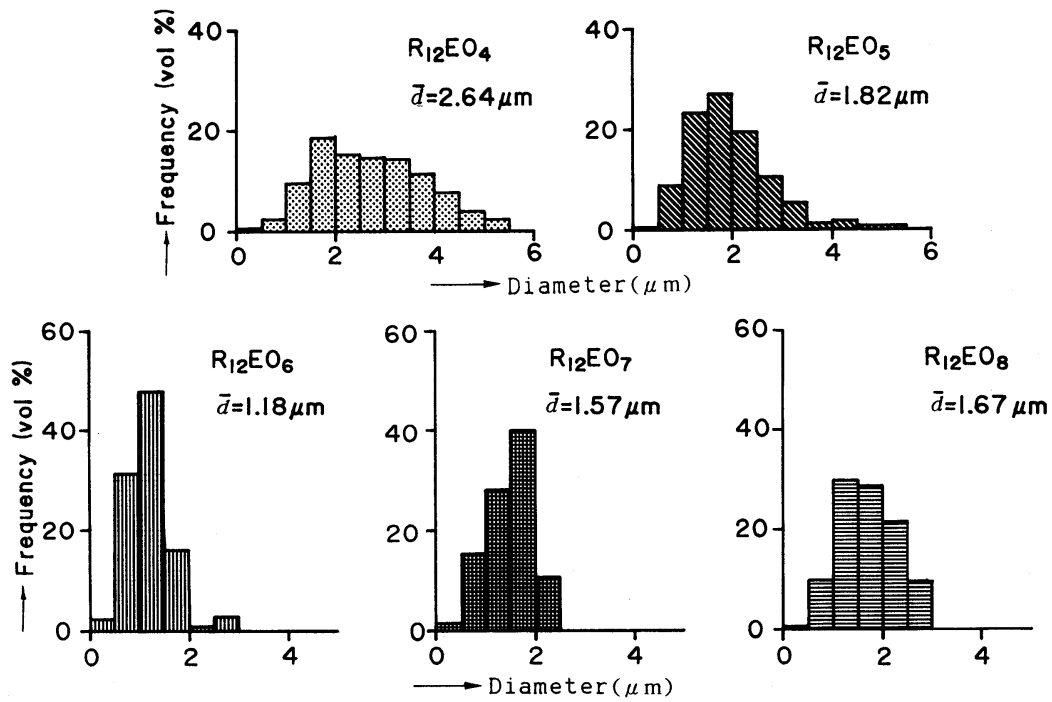

Fig.-9 Droplet size distribution of $\mathrm{O} / \mathrm{W}$ emulsions prepared by $\mathrm{D}$ phase emulsification ${ }^{12}$.

ば高温安定性の優れた乳化物を提供することができる。

\section{$6 \mathrm{D}$ 相乳化の化粧品への応用}

D相乳化を用いることにより, 安全性が高いにもかか わらず乳化力が弱く利用の困難であったポリ（オキシエ チレン) (20)ソルビタンモノステアラートや硬化ひま し油ポリ(オキシエチレン)付加物を単独で乳化剂として 用いた系でも乳化物の安定化が可能となる。Fig.-10 に非イオン界面活性剂のウサギ皮䖉一次刺激スコアを 示す ${ }^{18)}$ 。 $\mathrm{O} / \mathrm{W}$ エマルションを与える界面活剤の 場 合 (HLB 值は 10 以上), 親水性の界面活性剂のほうが皮膚 刺激は低い。また硬化ひまし油ポリ（オキシエチレン） 付加物はHLB にかかわりなく刺激が低い。このような 界面活性剂を用いた乳化系に $\mathrm{D}$ 相乳化は有用である。 $\mathrm{D}$ 相乳化法は高内相ゲル状エマルションのようなこれまで にない機能と感触を備えた化粧品開発にも役立ってい る。生産に際しては乳化温度等の製造条件や原料ロット 変動等の影響を受けにくいことから，安定した品質の製 品供給がより容易になった。このようなことから, 当社 では現在 9 品に $\mathrm{D}$ 相乳化を利用している。その一例と してデイ・アン・デイジェルクレンジングを紹介する (Fig. -11$)$ 。

本品は内相油が $70 \mathrm{wt} \%$ を越える高内相ゲル状エマ ルションであるが, 粒子径が $0.51 \mu \mathrm{m}$ と微細であるこ と, 使用した乳化剂の HLB 值が大きいことからその経 時及び温度安定性は高い。また $\mathrm{O} / \mathrm{W}$ タイプであるため 使用感, 使用性がよいにもかかわらず, 油性污れの除去 能力が高いという特性をもっている。

最後に本乳化法が化粧品工業以外の分野でも応用され

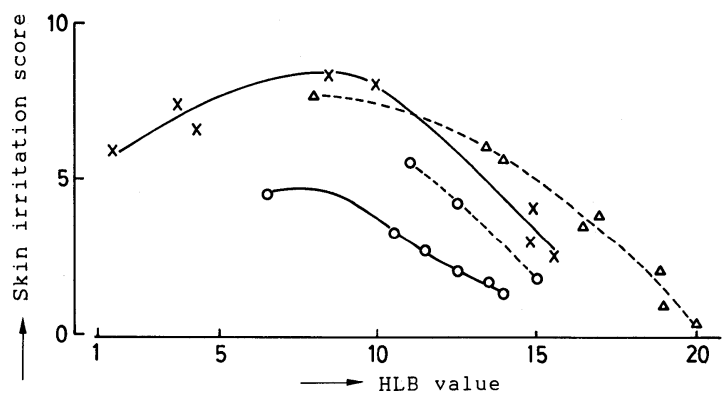

O-Hydrogenated castor oil poly (oxyethylene) adducts (100\%), O----Ester type $(100 \%), \times \longrightarrow$ Sorbitan type (100\%), $\triangle-$ Ester type (10\%)

Fig. -10 Relationship between HLB-value of nonionic surfactants and skin irritation score ${ }^{18)}$.

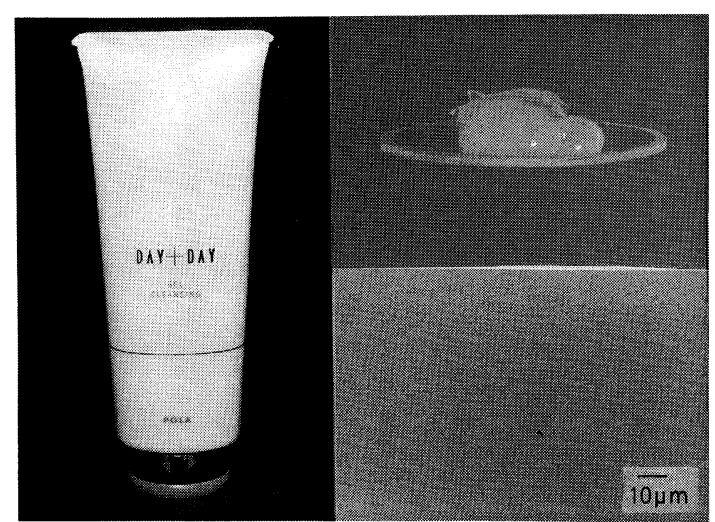

Fig.-11 POLA DAY+DAY GEL CLEANSING. 
ること, 及びエマルションの安定性, 生成メカニズムに 関する研究がさらに発展することを期待して筆を置きた い。

〔平成 3 年 (1991年) 8 月 5 日受理〕

\section{文献}

1) K. Shinoda, H. Saito, J. Colloid Interface Sci., 30, 258 (1969)

2) H. Saito, K. Shinoda, J. Colloid Interface Sci., 32, 647 (1970)

3) H. Sagitani, J. Am. Oil Chem. Soc., 58, 738(1981)

4) Y. Kumano, S. Nakamura, S. Tahara, S. Ohta, J. Soc. Cosmet. Chem., 28, 285 (1977)

5）鈴木 喬, 特許公告, 昭和 57-29213 (1982)

6）鈴木敏幸, 甲斐正信, 石田篤夫, 油化学, 34, 938 (1985)

7）鈴木敏幸, 武居ひろ子, 日化, 1986, 633

8）森田正道, 片田順規, 油化学, 40, 58 (1991)
9）鹭谷広道, 服部孝雄, 鍋田一男, 永井昌義, 日化, 1983, 1399

10）山田 稔, 藤田 哲, 特許公告, 昭和 45-32065 (1970)

11）鹭谷広道, 池田由美子, 大鄉保治, 油化学, 33, 156 (1984)

12) H. Sagitani, J. Dispersion Sci. Technol., 9, 115 (1988)

13) H. Sagitani, Y. Hirai, K. Nabeta, J. Jpn. Oil Chem. Soc. (Yukagaku), 35, 102 (1986)

14) H. Kunieda, J. Colloid Interface Sci., 114, 378 (1986)

15) N. Pilpel, M.E. Rabbani, J. Colloid Interface Sci., 119, 550 (1987)

16) 遠藤正行, 䉆谷広道, 油化学, 40, 133 (1991)

17) W.C. Griffin, J. Soc. Cosmet. Chem., 1, 311 (1949)

18）鈴木 守, “化粧品における生物科学の進歩”, フレグラ ンスジャーナル, (1987) p. 55 